\title{
BOOK TO MARKET RATIO AND EXPECTED STOCK RETURN: AN EMPIRICAL STUDY ON THE COLOMBO STOCK MARKET
}

\author{
Mohamed Ismail Mohamed Riyath \\ Sri Lanka Institute of Advanced Technological Education (SLIATE), \\ Sammanthurai, Sri Lanka. \\ riyath.i@sliate.ac.lk \\ Athambawa Jahfer \\ Department of Accountancy and Finance, \\ South Eastern University of Sri Lanka, Oluvil, Sri Lanka. \\ jahfer@seu.ac.lk
}

\begin{abstract}
The book to market capitalization of firms become one of the common risk factor on asset pricing models. The impact of book to market equity of firms on stock returns was initially found in US market and subsequently tested in many international markets both in developed and developing markets. However, the empirical test of value effect in Sri Lankan stock market seems hard to find in literature. Therefore, this study examines existence of value effect on stocks returns in the Colombo stock market as an emerging capital market. The analysis show a weak positive cross sectional relationship between stock return and Book to Market ratio of stock and existence of value effect.
\end{abstract}

Keywords: Book to market equity ratio, Colombo stock market, cross sectional relationship, Value effect.

\section{Introduction}

Treynor (1961), Sharpe (1964), Lintner (1965) and Mossin (1966) version of CAPM, version of Capital asset pricing model (CAPM) is commonly used to estimate cost of capital and to value financial asset. The CAPM postulates that the market factor is the only factors which determined variations of expected return of stocks. Earlier studies immediate after the formulation of the model found supportive evidences for CAPM that is there is a liner positive relationship existed between stock return and market factor Black (1972) and Fama and MacBeth (1973)However, subsequent studies found evidences in contrast to such existence of linier relationship. Friend and Blume (1970), Jensen, Black, and Scholes (1972) and
Stambaugh (1982) found a flat relationship between stock return and market factor. This findings risen the doubt on market factor as a single factor to determining the expected stock return. Due to the inability of the market factor, researchers focused on identification of other risk factor which determines stock return. Rosenberg, Reid, and Lanstein (1985) found the Book to market equity is able to determine the variations of expected return of stock. They states that there is a positive liner relationship exist between book to market equity and stock return. The stocks with high book to market equity ratio earn higher return than stock with low book to market equity ratio. The return differences between higher and lower book to 
market stocks is known as value premium.

The existence of value premium and positive relationship between stock return and book to market ratio were confirmed by the study of Fama and French (1992), Davis (1994), Lakonishok, Shleifer, and Vishny (1994), Asness (1997), Lewellen (1999), Asness, Porter, and Stevens (2000) in US market. The value premium is found in international market also, for example Chan, Hamao, and Lakonishok (1991) in Japan; Fama and French (1998) found value premium in international market such as Australia, Belgium, France, Germany, Hong Kong, Japan, Netherlands, Singapore, Sweden, Switzerland and UK; Fraser and Page (2000) in South Africa and Griffin (2002) in Canada. Capaul, Rowley, and Sharpe (1993) in developed market such as France, German, Switzerland, UK, Japan and USA; Rouwenhorst (1999) found in developing markets such as Argentina, Brazil, Chile, Greece, Indonesia, India, Jordan, Korea, Malaysia, Mexico, Nigeria, Philippines, Taiwan, Turkey, Venezuela and Zimbabwe. Even though the existence of the value premium were found in several developed and developing market, evidences for existence of value effect in Sri Lankan context is seems hard to find in literature. Hence, there is a question that weather the value effect is exist in Sri Lankan capital market. There is an another question that weather the cross sectional relationship between stock return and book to market ratio is exist in the Sri Lankan capital market. Therefore, this study empirically examines the existence of value effect and cross sectional relationship between stocks return and Book to Market ratio in the Colombo stock market.

\section{Literature review}

Rosenberg etal. (1985) test relationship between stocks return and BE/ME in US market. For this test they used 1,400 of the largest U.S. companies from the New York Stock Exchange (NYSE), and a few from other exchanges like the AMEX and NASDAQ in the COMPUSTAT database during the period between from January 1973-September 1984. They found a positive relation between average stock returns and $\mathrm{BE} / \mathrm{ME}$ (book value of common equity (BE) / market value of common equity (ME)). Higher return earned by the stocks which are having higher value of $\mathrm{BE} / \mathrm{ME}$ and lower return earned by stocks which are having lower value of $\mathrm{BE} / \mathrm{ME}$ than control for betas in US market.

Similarly, Chan et al. (1991) examined the related cross-sectional differences in returns on a Japanese stocks to four explanatory variables for returns were tested: size, book/market ratio, earnings/price ratio, cash flow/price ratio. They applied alternative statistical specifications and various estimation methods on Stocks data taken from the Tokyo Stock Exchange (TSE) during the period between from January 1971December 1988. They found a greater impact and significant positive relationship between the expected return and Book/market and cash flow/price ratios. However, after controlling for other variable, the impact of the Earning / Price ratio was insignificant.

Fama and French (1998) presented additional out-of-sample evidence on the value premium which examined returns on market, value, and growth portfolios in developed and emerging stock markets. They included thirteen major 
markets and in sixteen emerging markets during the period from 1974 to 1995 . They found that the value stocks tend to have higher average returns over growth stocks in twelve major market out of thirteen major markets during the test period. Also they found a value premium in emerging markets in the period 1987-1995.

Chui and Wei (1998) examine relationship between market beta, book-to-market equity, and size and expected stock returns relationship in five Pacific-Basin emerging markets such as Taiwan, Hong Kong, Thailand., Korea, and Malaysia during the period July 1977 through June 1993. The regression ran on based on portfolio data, result showed the significant negative size effect in Korean Market. The relationship between $\mathrm{BM} / \mathrm{ME}$ and return was significantly positive in Korea, Hong Kong and Malaysian Markets. However the significant negative relationship found in Malaysia, Thailand, Korea and Hong Kong when ran regression on based on individual stock. But same result as portfolio regression found book to market effect. Finally they concluded that a strong size effect in all five market while the book to market effect significantly impact in Hong Kong, Korea, and Malaysia only. However beta and return relationship is insignificant and flat.

Kothari, Shanken, and Sloan (1995) examine whether beta and Book to Market captures cross sectional variation in average returns. They used annual return (for estimating beta) and monthly returns (for estimating $\mathrm{BE} / \mathrm{ME}$ ) of all stocks in NYSE and AMEX during the period 1927 to 1990 . They observed a linear relationship between the beta and cross- section of expected stock returns. The BE/ME and returns relationship is much weaker than predicted by Fama and French (1992). Further they suggested that the data taken from the COMPUSTAT is affected by a selection bias and provides indirect evidence. Therefore they used S\&P 500 from 1947 to 1987 as alternative data source to overcome the bias on the data and the analysis found that the relationship between $\mathrm{BE} / \mathrm{ME}$ and average return is weak.

Lakonishok et al. (1994) formed portfolios based on value strategies to investigate the role of different characteristic of firms such as sales growth (GS), size, E/P, C/P and Book to market in explaining the cross-section of returns. They followed Fama and MacBeth (1973) methodology and used stocks from NYSE and AMEX during the period April 1968 to the end of April 1989 and found that all variable including $\mathrm{B} / \mathrm{M}$ have statistically significant predictive power in explaining return. But the size factor does not exist.

\section{Methodology}

The relevant market data for this study were taken from the official website of the Colombo Stock Exchange website (www.cse.lk) and CSE data library. In addition to the market data, the accounting data and number of shares of the company were taken from financial statements of respective companies published in annual reports. All listed companies are taken into considered for this study during the period from April 2000 to March 2013. However, the financial firms and stocks with negative BM ratios were excluded from the sample of this study. 
The book to market is calculated at end of March each year. The book to market is defined as the net assets as at end of financial year of a respective firm is divided by the market equity as at end of financial year. The market equity is defined as the number of shares outstanding times closing price as at end of last trading day of financial year end of respective firm. Book to Market equity ratio is sorted in ascending order and divided into ten equal number of portfolios. First decile portfolios labeled as D1, second decile portfolios labeled as D2 and so on. So that the stocks with smallest Book to Market ratio lays in the first portfolio D1 and the highest Book to Market ratio stocks lays in the last portfolio D10. The equally weighted monthly portfolio return is assigned to respective portfolio from April t to March $\mathrm{t}+1$. The portfolio is reformed each year at the end of March. The existence of value effect is tested by the return differences between two extreme decile portfolios.

\section{Hypothesis}

$H_{0}$ : value effect is not exist in the Colombo stock market.
$\mathrm{H}_{0}$ : average portfolio return of $\mathrm{D} 1 \geq$ average portfolio return of D10

$\mathrm{H}_{1}$ : value effect is exist in the Colombo stock market.

$\mathrm{H}_{1}$ : average portfolio return of $\mathrm{D} 1<$ average portfolio return of D10

The existence the cross sectional relationship between stock return and Book to Market ratio is tested by Fama and MacBeth (1973)Eugene two step regression on monthly return of ten portfolios and natural logarithm of Book to market equity ratio of respective portfolio. In the first step Estimate the slope coefficient for each of the 10 portfolios using time series regression equation 1 across portfolios. Then Portfolio returns regressed against the 10 estimated slope coefficient across time periods in the second step cross sectional regression equation 2.

$\mathrm{R}_{\mathrm{it}}=\alpha_{\mathrm{it}}+\beta_{\mathrm{it}} \mathrm{BTM}$ Equation 1

$\mathrm{R}_{\mathrm{t}}=\gamma_{0 \mathrm{t}}+\gamma_{1 \mathrm{t}} \beta_{\mathrm{t}}$ Equation 2

\section{Hypothesis}

$\mathrm{H}_{0}$ : The cross sectional relationship between

Table 1. Number of Stocks of Portfolios

\begin{tabular}{|l|l|l|l|l|l|l|l|l|l|l|l|}
\hline \multicolumn{10}{|c|}{ Number of Stocks } \\
\hline Year & D1 & D2 & D3 & D4 & D5 & D6 & D7 & D8 & D9 & D10 \\
\hline $\mathbf{2 0 0 0}$ & 15 & 14 & 15 & 14 & 13 & 16 & 15 & 16 & 14 & 13 \\
\hline $\mathbf{2 0 0 1}$ & 14 & 15 & 14 & 15 & 15 & 15 & 15 & 16 & 15 & 16 \\
\hline $\mathbf{2 0 0 2}$ & 15 & 13 & 14 & 12 & 13 & 16 & 15 & 15 & 14 & 14 \\
\hline $\mathbf{2 0 0 3}$ & 16 & 16 & 15 & 15 & 17 & 14 & 15 & 17 & 17 & 15 \\
\hline $\mathbf{2 0 0 4}$ & 15 & 18 & 18 & 15 & 17 & 17 & 17 & 18 & 18 & 18 \\
\hline $\mathbf{2 0 0 5}$ & 17 & 17 & 17 & 18 & 17 & 18 & 17 & 19 & 18 & 18 \\
\hline $\mathbf{2 0 0 6}$ & 16 & 17 & 17 & 19 & 18 & 19 & 19 & 19 & 19 & 18 \\
\hline $\mathbf{2 0 0 7}$ & 16 & 17 & 18 & 19 & 18 & 19 & 19 & 19 & 19 & 19 \\
\hline $\mathbf{2 0 0 8}$ & 15 & 19 & 18 & 19 & 18 & 19 & 19 & 18 & 19 & 18 \\
\hline $\mathbf{2 0 0 9}$ & 18 & 19 & 18 & 18 & 19 & 19 & 17 & 19 & 19 & 18 \\
\hline $\mathbf{2 0 1 0}$ & 18 & 18 & 18 & 19 & 18 & 17 & 19 & 18 & 18 & 18 \\
\hline $\mathbf{2 0 1 1}$ & 18 & 18 & 18 & 18 & 19 & 18 & 19 & 18 & 19 & 18 \\
\hline $\mathbf{2 0 1 2}$ & 18 & 18 & 19 & 18 & 18 & 19 & 18 & 19 & 18 & 18 \\
\hline
\end{tabular}


stock return and Book to Market ratio is not exist in the Colombo stock market.

$$
\mathrm{H}_{0}: \bar{\gamma}_{\mathrm{t}} \leq 0
$$

$\mathrm{H}_{1}$ :The positive cross sectional relationship between stock return and Book to Market ratio is exist in the Colombo stock market.

$$
\mathrm{H}_{1}: \bar{\gamma}_{\mathrm{t}}>0
$$

\section{RESULTS AND DISCUSSION}

Table 1 shows number of stocks included in the sample of this study in each decile portfolio at end of March $t$ each year.

Table 2 shows average book to market value for respective decile portfolio each year as at end of March. The given book to market value is calculated by aggregating whole book to market value of each stock and divided by number of stocks outstanding of the respective portfolio. The values demonstrate that the average book to market value is increases from low decile book to market portfolio to high decile portfolio each year.

Table 3 shows average annual monthly equally weighted return for respective decile portfolio each year as at end of March $t+1$. The average annual monthly return of each stock is the average of twelve month return from April $t$ to March $\mathrm{t}+1$. The given average annual monthly portfolio return of each decile portfolio is calculated by aggregating whole average annual monthly return of each stock and divided by number of stocks outstanding of the respective portfolio. The values indicate that the highest decile portfolio return is higher than the lowest decile portfolio. The differences of return between highest and smallest decile portfolios, provide evidence for existence size effect.

Table 4 shows the test result of Pearson correlation between Natural Logarithm of

Table 2. Book to Market Ratio of Portfolio

\begin{tabular}{|c|c|c|c|c|c|c|c|c|c|c|}
\hline \multicolumn{10}{|c|}{ BTM } \\
\hline Year & D1 & D2 & D3 & D4 & D5 & D6 & D7 & D8 & D9 & D10 \\
\hline 2000 & 0.36 & 0.89 & 1.20 & 1.46 & 1.69 & 2.06 & 2.53 & 3.33 & 4.33 & 8.46 \\
\hline 2001 & 0.37 & 0.98 & 1.48 & 1.79 & 2.30 & 2.72 & 3.21 & 3.82 & 5.03 & 14.71 \\
\hline 2002 & 0.32 & 0.85 & 1.22 & 1.57 & 1.86 & 2.17 & 2.55 & 3.24 & 3.99 & 7.84 \\
\hline 2003 & 0.30 & 0.67 & 0.92 & 1.17 & 1.46 & 1.80 & 2.19 & 2.75 & 3.69 & 119.84 \\
\hline 2004 & 0.29 & 0.49 & 0.73 & 0.95 & 1.14 & 1.48 & 1.89 & 2.31 & 2.99 & 74.54 \\
\hline 2005 & 0.11 & 0.30 & 0.46 & 0.61 & 0.74 & 0.92 & 1.13 & 1.40 & 1.89 & 56.79 \\
\hline 2006 & 0.14 & 0.35 & 0.50 & 0.65 & 0.76 & 0.89 & 1.10 & 1.32 & 1.70 & 50.99 \\
\hline 2007 & 0.17 & 0.37 & 0.56 & 0.73 & 0.89 & 1.04 & 1.25 & 1.48 & 1.96 & 32.23 \\
\hline 2008 & 0.15 & 0.42 & 0.64 & 0.79 & 0.90 & 1.03 & 1.28 & 1.57 & 1.89 & 21.32 \\
\hline 2009 & 0.29 & 0.61 & 0.85 & 1.09 & 1.34 & 1.66 & 2.06 & 2.49 & 3.04 & 18.25 \\
\hline 2010 & 0.18 & 0.38 & 0.48 & 0.59 & 0.71 & 0.85 & 1.03 & 1.27 & 1.83 & 17.52 \\
\hline 2011 & 0.09 & 0.21 & 0.30 & 0.37 & 0.45 & 0.52 & 0.65 & 0.87 & 1.07 & 13.30 \\
\hline 2012 & 0.18 & 0.34 & 0.50 & 0.61 & 0.74 & 0.86 & 1.02 & 1.36 & 1.66 & 4.24 \\
\hline
\end{tabular}


Table 3. Average Monthly Return of Portfolios

\begin{tabular}{|c|c|c|c|c|c|c|c|c|c|c|}
\hline \multicolumn{10}{|c|}{ Average Monthly Return } \\
\hline Year & D1 & D2 & D3 & D4 & D5 & D6 & D7 & D8 & D9 & D10 \\
\hline $\mathbf{2 0 0 0}$ & -1.66 & -1.10 & 0.24 & -0.21 & 1.26 & 0.05 & 0.86 & 0.17 & -0.01 & 1.41 \\
\hline $\mathbf{2 0 0 1}$ & 3.44 & 5.44 & 3.93 & 2.04 & 2.79 & 4.49 & 5.12 & 3.19 & 7.01 & 5.37 \\
\hline $\mathbf{2 0 0 2}$ & 2.82 & 2.06 & 3.67 & 1.72 & 0.99 & 2.88 & 4.01 & 3.12 & 3.01 & 9.50 \\
\hline $\mathbf{2 0 0 3}$ & 10.52 & 5.08 & 4.60 & 4.05 & 6.18 & 5.00 & 3.56 & 3.27 & 10.33 & 13.02 \\
\hline $\mathbf{2 0 0 4}$ & 6.91 & 4.47 & 4.85 & 8.68 & 4.93 & 5.97 & 5.43 & 6.89 & 17.33 & 16.87 \\
\hline $\mathbf{2 0 0 5}$ & 1.77 & 0.89 & 2.87 & 3.70 & 2.47 & 1.78 & 2.84 & 5.33 & 6.00 & 5.50 \\
\hline $\mathbf{2 0 0 6}$ & -1.10 & 0.30 & 1.30 & -1.56 & 5.40 & 1.99 & 1.60 & 1.18 & 1.05 & 1.76 \\
\hline $\mathbf{2 0 0 7}$ & 3.46 & -0.21 & 2.01 & 1.13 & 1.69 & 2.66 & 2.58 & 5.90 & 2.87 & 6.78 \\
\hline $\mathbf{2 0 0 8}$ & 0.03 & -1.25 & -1.52 & -2.74 & -2.01 & -1.10 & -2.36 & 1.21 & -0.93 & -0.60 \\
\hline $\mathbf{2 0 0 9}$ & 8.79 & 5.90 & 5.29 & 8.71 & 9.45 & 9.48 & 7.53 & 10.46 & 8.49 & 9.45 \\
\hline $\mathbf{2 0 1 0}$ & 21.40 & 6.35 & 7.46 & 6.89 & 10.47 & 7.07 & 6.93 & 9.39 & 8.20 & 12.44 \\
\hline
\end{tabular}

Book to Market equity of each stock and monthly return of each stock. The correlation coefficient is 0.046 on 24014 observations during the study period. The $p$ value is 0.00 is less than alpha value of 0.05 . Therefore the null hypothesis is rejected at $95 \%$ confidence level and the correlation is significant. It is evidence that there is a weak positive correlation between market capitalization and stock return exist in stocks listed on CSE during the study period.
Table 5 shows descriptive statistic summary of monthly observation of each portfolio average monthly return from April 2000 to March 2012. The average portfolio return of highest decile portfolio D10 return is $5.93 \%$ per month while lowest decile portfolio D1 return is 3.63\% per month. The differences between highest and lowest decile portfolio return is $2.2972 \%$, Standard Deviation is $14.99 \%$, Standard Error Mean is $1.20029 \%$ and $t$ statistic is $1.914 \%$

Table 4 Correlation between Monthly Stock Return and BTM

\begin{tabular}{|l|l|r|r|}
\hline \multicolumn{3}{|c|}{ Correlations } \\
\hline \multirow{4}{*}{ Return } & \multicolumn{1}{|c|}{ Return } & \multicolumn{1}{|c|}{ Ln BTM } \\
\hline & Pearson Correlation & 1 & $.046^{* *}$ \\
\cline { 2 - 4 } & Sig. (2-tailed) & & .000 \\
\cline { 2 - 4 } & $\mathrm{N}$ & 25349 & 25349 \\
\hline \multirow{4}{*}{ Ln BTM } & Pearson Correlation & $.046^{* *}$ & 1 \\
\cline { 2 - 4 } & Sig. (2-tailed) & .000 & \\
\cline { 2 - 4 } & $\mathrm{N}$ & 25349 & 25349 \\
\hline \multirow{2}{*}{$* *$. Correlation is significant at the 0.01 level (2-tailed). } \\
\hline
\end{tabular}


Book to Market Ratio and Expected Stock Return:

An Empirical Study on the Colombo Stock Market

Table 5. Descriptive Statistics

\begin{tabular}{|l|r|r|r|r|r|r|r|r|r|r|}
\hline \multicolumn{1}{|c|}{ Statistic } & \multicolumn{1}{c|}{ D1 } & \multicolumn{1}{c|}{ D2 } & \multicolumn{1}{c|}{ D3 } & \multicolumn{1}{c|}{ D4 } & \multicolumn{1}{c|}{ D5 } & \multicolumn{1}{c|}{ D6 } & \multicolumn{1}{c|}{ D7 } & \multicolumn{1}{c|}{ D8 } & \multicolumn{1}{c|}{ D9 } & D10 \\
\hline No. of observations & 156 & 156 & 156 & 156 & 156 & 156 & 156 & 156 & 156 & 156 \\
\hline Mean & 3.63 & 1.82 & 2.44 & 2.47 & 2.98 & 3.14 & 2.69 & 4.02 & 4.01 & 5.93 \\
\hline Median & 1.25 & 2.04 & 2.14 & 1.24 & 1.86 & 1.88 & 2.12 & 2.79 & 2.29 & 2.43 \\
\hline Minimum & -21.79 & -21.25 & -22.30 & -21.37 & -20.12 & -17.72 & -20.89 & -21.72 & -23.29 & -25.30 \\
\hline Maximum & 127.78 & 23.69 & 28.05 & 35.04 & 58.31 & 31.42 & 32.19 & 36.25 & 38.46 & 92.97 \\
\hline Range & 149.57 & 44.93 & 50.34 & 56.41 & 78.43 & 49.14 & 53.08 & 57.97 & 61.75 & 118.27 \\
\hline Standard deviation (n-1) & 14.88 & 8.26 & 8.01 & 8.71 & 10.47 & 9.23 & 9.01 & 10.21 & 10.56 & 15.91 \\
\hline Standard error of the mean & 1.19 & 0.66 & 0.64 & 0.70 & 0.84 & 0.74 & 0.72 & 0.82 & 0.85 & 1.27 \\
\hline Mean absolute deviation & 9.09 & 6.38 & 6.25 & 6.51 & 7.52 & 7.22 & 6.92 & 7.75 & 8.15 & 10.89 \\
\hline
\end{tabular}

with 155 degree of freedom. The statistical test is shows that the $\mathrm{p}$ value is 0.0285 , which is less than alpha value of 0.05 . Therefore null hypothesis is rejected at $95 \%$ confidence level. The alternative hypothesis is the average monthly return of highest decile portfolio D10 is higher than lowest decile portfolio. The study provides evidence for existence of value effect in the Colombo stock market during the study period.

Table 6 provides the test result of Fama and MacBeth (1973) two step regression on monthly return of ten portfolios and natural logarithm of Book to market equity ratio of respective portfolio. The Fama and MacBeth (1973) coefficient of Book to market ratio is 0.7862 and the respective statistics is 45.30 . Therefore, the Fama and MacBeth (1973) of Book to market ratio is highly significant and rejects null hypothesis that the cross sectional relationship between stocks return and Book to Market ratio is not exist in the Colombo stock market. Therefore, the result shows significant positive relationship between portfolio return and Book to market ratio and provides evidence for existence of value effect during the study period in Colombo stock exchange.

\section{Conclusion}

This study examines existence of value effect on stocks returns in the Colombo stock market. The sample of study includes all non-financial companies listed on main board of Colombo stock exchange during the period from 2000 to 2013. All sample of stocks are formed into ten portfolios based on book to market ratio and equally weighted average monthly portfolio return is calculated and assigned to respective decile portfolios at the end of each year. The existence of vale effect is estimated by the

Table 6

\begin{tabular}{|l|r|}
\hline \multicolumn{2}{|c|}{ Fama and Macbeth (1973) Test } \\
\hline FM Coefficient & 0.786283 \\
\hline Observation & 156 \\
\hline Variance & 0.04699 \\
\hline SD & 0.216771 \\
\hline T Statistics of FM & 45.30428 \\
\hline
\end{tabular}


differences of portfolio return between highest and lowest book to market decile portfolio. The analyses show that the highest decile portfolio of stocks earns higher return than lowest decile portfolio of stocks. Therefore, the study concludes that there is a value effect exist in the Colombo stock market during the study period. The existence of cross sectional relationship between stock return and Book to Market ratio is estimated by the Fama and MacBeth (1973) cross sectional two step regression. The analyses show that positive relationship between portfolio return and Book to market ratio and provides evidence for existence of value effect during the study period in Colombo stock exchange. The findings of this study are consistent with the previous studies.

\section{Reffernces}

Asness, C. S. (1997). The interaction of value and momentum strategies. Financial Analysts Journal, 53(2), 29-36.

Asness, C. S., Porter, R. B., \& Stevens, R. L. (2000). Predicting stock returns using industry-relative firm characteristics. Available at SSRN 213872.

Black, F. (1972). Capital market equilibrium with restricted borrowing. Journal of business, 444-455.

Capaul, C., Rowley, I., \& Sharpe, W. F. (1993). International value and growth stock returns. Financial Analysts Journal, 49(1), 27-36.

Chan, L. K., Hamao, Y., \& Lakonishok, J. (1991). Fundamentals and stock returns in Japan. The Journal of Finance, 46(5), 1739-1764.
Chui, A. C., \& Wei, K. J. (1998). Book-tomarket, firm size, and the turn-of-theyear effect: Evidence from Pacific-Basin emerging markets. Pacific-Basin Finance Journal, 6(3), 275-293.

Davis, R. J. (1994). MAPKs: new JNK expands the group. Trends in biochemical sciences, 19(11), 470-473.

Fama, E. F., \& French, K. R. (1992). The cross section of expected stock returns. The Journal of Finance, 47(2), 427-465.

Fama, E. F., \& French, K. R. (1998). Value versus growth: The international evidence. Journal of Finance, 1975-1999.

Fama, E. F., \& MacBeth, J. D. (1973). Risk, return, and equilibrium: Empirical tests. The Journal of Political Economy, 607636.

Fraser, E., \& Page, M. (2000). Value and momentum strategies: Evidence from the Johannesburg Stock Exchange. Investment Analysts Journal, 29(51), 25-35.

Friend, I., \& Blume, M. (1970). Measurement of portfolio performance under uncertainty. The American Economic Review, 561-575.

Griffin, J. M. (2002). Are the Fama and French factors global or country specific? Review of Financial Studies, 15(3), 783-803.

Jensen, M. C., Black, F., \& Scholes, M. S. (1972). The capital asset pricing model: Some empirical tests.

Kothari, S. P., Shanken, J., \& Sloan, R. G. (1995). Another look at the cros section of expected stock returns. The Journal of Finance, 50(1), 185-224. 
Lakonishok, J., Shleifer, A., \& Vishny, R. W. (1994). Contrarian investment, extrapolation, and risk. The Journal of Finance, 49(5), 1541-1578.

Lewellen, J. (1999). The time-series relations among expected return, risk, and book-tomarket. Journal of Financial Economics, 54(1), 5-43.

Lintner, J. (1965). The valuation of risk assets and the selection of risky investments in stock portfolios and capital budgets. The review of economics and statistics, 13-37.

Mossin, J. (1966). Equilibrium in a capital asset market. Econometrica: Journal of the Econometric Society, 768-783.

Rosenberg, B., Reid, K., \& Lanstein, R. (1985). Persuasive evidence of market inefficiency. The Journal of Portfolio Management, 11(3), 9-16.
Rouwenhorst, K. G. (1999). Local return factors and turnover in emerging stock markets. The Journal of Finance, 54(4), 1439-1464.

Sharpe, W. F. (1964). Capital asset prices: A theory of market equilibrium under conditions of risk*. The Journal of Finance, 19(3), 425-442.

Stambaugh, R. F. (1982). On the exclusion of assets from tests of the two-parameter model: A sensitivity analysis. Journal of Financial Economics, 10(3), 237-268.

Treynor, J. L. (1961). Toward a theory of market value of risky assets. 